\title{
The importance of feedback for medical students' development
}

This article was published in the following Dove Press journal:

Advances in Medical Education and Practice

22 March 2017

Number of times this article has been viewed

\section{Rahul Rajesh Amin \\ Rohin Patel \\ Prashant Bamania}

Faculty of Medicine, Imperial College London, Kensington, London,

United Kingdom
Correspondence: Rahul Rajesh Amin Faculty of Medicine, Imperial College London, Kensington, London SW7 2AZ, United Kingdom

Email rahul.r.amin 12@imperial.ac.uk

\section{Dear editor}

We read with great interest the study by McKenzie et al, ${ }^{1}$ which explores the impact of providing feedback to students on their ability to carry out a clinical procedure. This study was particularly interesting to us as fifth-year medical students at Imperial College London who have learnt several clinical skills during rotations. A noteworthy finding was that education involving providing feedback to students had a positive impact on their performance. ${ }^{1}$ Furthermore, the recommendation that clinical skills training be accompanied with feedback resonated strongly with us.

During our first clinical year, we had regular teaching sessions about clinical skills including venepuncture, cannulation, and suturing. Despite being encouraged to engage in self-assessment, we found this was less effective than external feedback. Ward et $\mathrm{al}^{2}$ showed the limitations of self-assessment in creating improvements; however, Srinivasan et $\mathrm{al}^{3}$ concluded that feedback was pivotal in improving selfassessment. We practiced the skills we learnt on simulation dummies. Here, we were individually supervised by clinical teaching fellows who provided us with detailed, student-specific feedback and constructive criticism of our performance, allowing us to better reflect on our own abilities and where improvements can be made and implemented. The timeliness and level of student-specific feedback we received motivated us to keep working on the deficiencies identified. Over time this all helped improve our abilities to perform clinical skills. This provided a strong platform from which we could further enhance our skills through practice in real clinical scenarios. Doctors and nurses supervised us, provided feedback, and advocated changes so we became more competent and confident in our abilities, but importantly, we also learnt how to build strong rapport with patients and make them as comfortable as possible.

In some rotations of our second clinical year, we often ran consultations under doctor supervision. After consultations, doctors provided us with personalized feedback about how we could improve which we could take away and put into practice. We learnt crucial questions to ask during history taking, ways of building patient rapport, and tips on becoming more competent at examinations. Feedback is given and stored on a common app on student's individual iPads. This is useful for future reference because we can easily see where we went wrong before, and exactly how we can improve. Ashby et $\mathrm{al}^{4}$ concluded that electronic feedback can enhance both 
the quantity and quality of the feedback itself. The feedback received was invaluable and helped boost our confidence in our own abilities.

Thus, we consider feedback an important learning tool for students. We agree that providing student's feedback can improve their abilities to perform clinical skills ${ }^{1}$ and also take histories, perform examinations, and tend to patient comfort. We suggest that electronic feedback be implemented in all forms of medical training. Hence, students can easily access and store feedback for future reference and remind themselves of what went well before and what could be improved. We feel that providing students regular feedback about their clinical performances will be invaluable to their development as competent doctors.

\section{Disclosure}

The authors declare no conflicts of interest in this communication.

\section{References}

1. McKenzie S, Burgess A, Mellis C. Interns reflect: the effect of formative assessment with feedback during pre-internship. Adv Med Educ Pract. 2017;8:851-856.

2. Ward M, Gruppen L, Regehr G. Measuring self-assessment: current state of the art. Adv Health Sci Educ Theory Pract. 2002;7(1):63-80.

3. Srinivasan M, Hauer KE, Der-Martirosian C, Wilkes M, Gesundheit N. Does feedback matter? Practice-based learning for medical students after a multi-institutional clinical performance examination. Med Educ. 2007;41(9):857-865.

4. Ashby SE, Snodgrass SH, Rivett DA, Russell T. Factors shaping e-feedback utilization following electronic objective structured clinical examinations. Nurs Health Sci. 2016;18(3):362-369. 


\section{Authors' reply \\ Susan McKenzie' \\ Annette Burgess ${ }^{2}$ \\ Craig Mellis'}

'Central Clinical School, ${ }^{2}$ Education Office, Sydney Medical School, The University of Sydney, Sydney, NSW, Australia

Correspondence: Susan McKenzie

Central Clinical School, Sydney Medical School, The University of

Sydney, Building 63, Level 4, Royal Prince Alfred Hospital Missenden

Road, Camperdown, Sydney 2050, NSW 2050, Australia

Tel +6I 295156548

Email susan.mckenzie@sydney.edu.au

\section{Dear editor}

Thank you for the opportunity to respond to the letter by Dr Amin and colleagues.

We wish to thank Dr Amin and colleagues for their interest in our recent article ${ }^{1}$ and have found their feedback encouraging for our work.
We find the use of electronic feedback to be of particular interest as we are currently developing a similar electronic application for the use of students' "smart phones". We anticipate by capturing feedback in this manner, students have a great opportunity to reflect on their procedural skills performance, and to be able to improve their skills when necessary.

\section{Disclosure}

The authors declare no conflicts of interest in this communication.

\section{Reference}

1. McKenzie S, Burgess A, Mellis C. Interns reflect: the effect of formative assessment with feedback during pre-internship. Adv Med Educ Pract. 2017;8:51-56.

Dove Medical Press encourages responsible, free and frank academic debate. The content of the Advances in Medical Education and Practice 'letters to the editor' section does not necessarily represent the views of Dove Medical Press, its officers, agents, employees, related entities or the Advances in Medical Education and Practice editors. While all reasonable steps have been taken to confirm the content of each letter, Dove Medical Press accepts no liability in respect of the content of any letter, nor is it responsible for the content and accuracy of any letter to the editor.

\section{Publish your work in this journal}

Advances in Medical Education and Practice is an international, peerreviewed, open access journal that aims to present and publish research on Medical Education covering medical, dental, nursing and allied health care professional education. The journal covers undergraduate education, postgraduate training and continuing medical education including emerging trends and innovative models linking education, research, and health care services. The manuscript management system is completely online and includes a very quick and fair peer-review system. Visit http://www.dovepress.com/testimonials.php to read real quotes from published authors.

Submit your manuscript here: http://www.dovepress.com/advances-in-medical-education-and-practice-journal 